Utah State University

DigitalCommons@USU

The Bark Beetles, Fuels, and Fire Bibliography

Quinney Natural Resources Research Library,

S.J. and Jessie E.

2013

\title{
Forest Development and Carbon Dynamics After Mountain Pine Beetle Outbreaks
}

\author{
E. Matthew Hansen
}

Follow this and additional works at: https://digitalcommons.usu.edu/barkbeetles

Part of the Ecology and Evolutionary Biology Commons, Entomology Commons, Forest Biology Commons, Forest Management Commons, and the Wood Science and Pulp, Paper Technology Commons

\section{Recommended Citation}

Hansen, E. Matthew. 2013. Forest Development and Carbon Dynamics After Mountain Pine Beetle Outbreaks. Forest Science.

This Article is brought to you for free and open access by the Quinney Natural Resources Research Library, S.J. and Jessie E. at DigitalCommons@USU. It has been accepted for inclusion in The Bark Beetles, Fuels, and Fire Bibliography by an authorized administrator of DigitalCommons@USU. For more information, please contact digitalcommons@usu.edu.

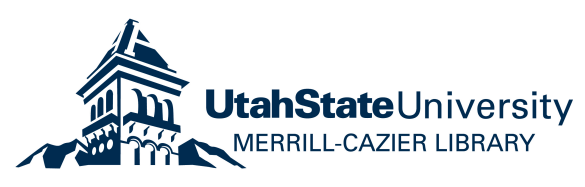




\section{Forest Development and Carbon Dynamics after Mountain Pine Beetle Outbreaks}

\section{E. Matthew Hansen}

Mountain pine beetles periodically infest pine forests in western North America, killing many or most overstory pine stems. The surviving secondary stand structure, along with recruited seedlings, will form the future canopy. Thus, even-aged pine stands become multiaged and multistoried. The species composition of affected stands will depend on the presence of nonpines and outbreak severity, among other factors, and can range from continued dominance by pines to hastened conversion to more shade-tolerant species. The loss of mature host trees results in reductions of ecosystem carbon productivity. The surviving and recruited stems, however, grow more quickly in response to the reduced competition, and carbon productivity and live basal area recover to preoutbreak levels within a few years or decades. Infestations may result in system carbon storage reductions, relative to storage among undisturbed developmental trajectories, mostly because of the temporary decrease in carbon productivity. Carbon losses in infested stands are slow as a result of recalcitrance of snags and coarse woody debris. Recalcitrant dead pools combined with recovering live pools results in fairly stable total ecosystem carbon storage among infested stands. Infested stands may switch from net carbon sinks to net carbon sources but typically recover within $5-20$ years.

Keywords: forest recovery, carbon productivity, carbon storage, bark beetle impacts, disturbance ecology

$\mathrm{M}$ ountain pine beetle (MPB) (Dendroctonus ponderosae Hopkins) is considered the most destructive forest insect in western North America (Furniss and Carolin 1977, p. 353). This organism is capable of killing most overstory pines across multiple stands or an entire landscape, particularly in lodgepole pine type (Pinus contorta Dougl. Ex Loud.). Outbreaks in recent years have been unusually widespread and severe, and their impact on ecological processes has been identified as a research gap (Bentz et al. 2009). MPB outbreaks directly affect forest structure, with cascading ecological effects including changes in forest development, primary productivity, and biogeochemical dynamics. In this article, I will first review how MPB outbreaks alter forest structure and modify the course of ecological succession. Because, in lodgepole pine systems, autotrophic inputs are the main drivers of carbon dynamics (Brown et al. 2012, Kashian et al. 2013, Moore et al. 2013), this framework is essential as my review turns to the effects of MPBcaused pine mortality on ecosystem carbon storage and productivity. This review is focused on lodgepole pine systems, especially regarding carbon dynamics, but I include literature from ponderosa pine (Pinus ponderosa Dougl. Ex Laws.) and whitebark pine (Pinus albicaulis Engelm.) systems where available. In the interest of parsi- mony, I will disregard climate disruption influences on bark beetle activity (Seidl et al. 2008, Bentz et al. 2010) and host species distributions (Rehfeldt et al. 2012).

It should be remembered that MPB is a native organism in the pine forests of western North America, albeit one exhibiting invasive range expansion (de la Giroday et al. 2012). Furthermore, MPB has been infesting its hosts for thousands (Brunelle et al. 2008), if not millions (Sturgeon and Mitton 1982), of years. Finally, stand-replacing wildfires notwithstanding, MPB outbreaks affect mature (e.g., $>80$ years old) lodgepole pine systems every 20-50 years (Cole and Amman 1980, Alfaro et al. 2004, Axelson et al. 2009) and, perhaps, ponderosa pine in South Dakota every 11-20 years (Schmid and Mata 1996). Given that these systems undergo renewal despite repeated MPB disturbance, it is apparent that MPB is an integral component of the ecosystems within which it operates.

It may also be useful, within a topic of disturbance ecology, to briefly consider broad-scale drivers of ecosystem dynamics. Holling (1992) made us aware that cycles of birth, growth, death, and renewal occur at many temporal and spatial scales, including entire ecosystems. In Holling's model, ecosystems become "over-connected" (i.e., increasingly fragile) as they mature and are eventually

Manuscript received March 12, 2013; accepted August 6, 2013; published online September 19, 2013.

Affiliations: Earl Matthew Hansen (matthansen@fs.fed.us), USDA Forest Service, Rocky Mountain Research Station, Logan, UT.

Acknowledgments: A portion of this work was funded by the USDA Forest Service, Forest Health Monitoring-Evaluation Monitoring program (project INT-EM-B-10-03). Thanks to Michael C. Amacher, Charles C. Rhoades, and Barbara J. Bentz, as well as two anonymous reviewers, for helpful comments regarding earlier versions of this article. James Vandygriff assisted with production of the figures. 
released by disturbance agents. The system is then reorganized by heterotrophs, setting the stage for a new phase of autotrophic exploitation (Holling 1992). Grounded on Prigogine and Stengers' (1984) theory of self-organizing structures as dissipaters of system disequilibrium, Kay (2000) explicitly framed Holling's cycle in terms of ecosystem thermodynamics. Autotrophs self-organize to dissipate the solar exergy (useful energy) gradient, leading to a second exergy gradient in the form of stored carbon chains. As carbon storage increases with time, the system becomes increasingly out of balance, thermodynamically, with the surrounding environment and eventually some other structure self-organizes to dissipate the stored exergy. The release of stored exergy in ecosystems is initiated by disturbance agents, such as fire, storms, diseases, insects, and land-use activities such as timber harvesting and grazing, and is completed by microbial heterotrophs (Kay 2000). Thus, thermodynamics might be used to predict both the creation of an ecosystem in response to the solar exergy gradient and the destruction of that ecosystem in response to the accumulated biomass exergy gradient. The implication is that ecosystem creation with destruction is an inexorable dance; the fullness of each contains the seeds of the other. Improved understanding of the ecological "role" of MPB outbreaks can be expected to result in enlightened and more effective management of pine forests and MPB populations.

\section{Host Mortality Patterns and Residual Forest Lodgepole Pine}

Under epidemic conditions, MPBs prefer larger diameter trees with relatively thick phloem, and the mortality rate of large diameter overstory trees can approach $100 \%$ in mature stands (Roe and Amman 1970, Shore et al. 2006). MPB's preference for larger diameter trees appears to hold regardless of outbreak severity or whether the forest has previously experienced an outbreak (Kashian et al. 2011). The mortality rate declines with decreasing diameter (Safranyik 2004), typically resulting in survivors among subcanopy stems even if most overstory trees are killed throughout the stand or forest. Although single-storied stands of large diameter pines may undergo near complete loss of lodgepole pine, average stem mortality at the landscape level will range from 25 to $50 \%$ because of age and size class diversity across stands (Shore et al. 2006). That is, increasing spatial scales have increasing diversity in stand structure and, thus, reduced susceptibility to MPB infestation. Aerial surveys from the recent widespread and severe outbreak in British Columbia confirmed the relative lack of extreme mortality at the landscape scale. At a spatial scale of $16 \mathrm{ha},<1 \%$ of the affected area was classified with $100 \%$ mortality, whereas just $5 \%$ was classified with $>85 \%$ mortality (Walton 2011, Simard et al. 2012).

At the stand level, the overall course of an outbreak may last 10 years, including pre- and postepidemic years. The epidemic phase of an outbreak, defined as $>7$ infested stems ha $^{-1}$ year $^{-1}$, lasts about 6 years (Cole and Amman 1980). In Wyoming studies, mortality peaked during the third year of the epidemic phase with the loss of $30-40 \%$ of large diameter trees and $5-10 \%$ of small diameter trees (Cole et al. 1976, Klein et al. 1978). There is considerable variability in lodgepole pine mortality but, generally, not all pines are killed and, of those that are, not all are killed in a single season (Simard et al. 2012 and references therein). Among other factors such as outbreak severity and residual stand structure, this pattern has consequences with regard to carbon cycling, particularly forest floor dynamics (discussed below).

Because MPB preferentially infests larger diameter trees, surviv- ing lodgepole pines generally come from the suppressed and intermediate crown classes or are slow-growing canopy trees with thin phloem (Roe and Amman 1970, Coates et al. 2006, Hawkins et al. 2012). Of course, nonpines also survive a MPB outbreak (but see Huber et al. 2009). Hawkins et al. (2012) reported that overstory and understory trees survived the recent outbreaks in central British Columbia at rates sufficient for most affected stands to be considered acceptably well stocked (>600 stems ha $^{-1}$ ). Most surviving pines were in younger stand age classes, whereas older age classes were dominated by spruce (Picea spp.) and fir (Abies spp.). In MPBaffected stands in southcentral British Columbia, there was more variability in residual stand conditions as only about one-half of surveyed stands were considered adequately stocked, and many stands had species other than lodgepole pine in their canopies (Vyse et al. 2009). The Cariboo-Chilcotin region of British Columbia also had considerable variability in stocking after the recent MPB outbreak, but surviving lodgepole pine continued to dominate the sampled stands in three of five biogeoclimatic zones (Coates et al. 2006). In the United States, postoutbreak stands may or may not be dominated by lodgepole pine, depending on the host mortality rates and the density of more shade-tolerant species (Amman 1977). In Colorado studies, the recent outbreak resulted in the loss of most lodgepole pine overstory, but surveyed stands maintained an average of 600-1250 stems ha ${ }^{-1}$ of lodgepole pine $(\mathrm{dbh} \geq 2.5 \mathrm{~cm})$ and $170-400$ stems ha $^{-1}$ of other species (Klutsch et al. 2009, Collins et al. 2011). Elsewhere in Colorado, surveyed stands in heavily infested areas averaged about 500 surviving canopy stems ha ${ }^{-1}$ plus enough seedlings and saplings to bring total stem density to nearly 4,000 $\mathrm{ha}^{-1}$ (Diskin et al. 2011). In Wyoming, stands with greatly reduced overstory lodgepole pine had adequate advance regeneration to meet prescribed stocking levels, even just considering lodgepole pine stems (Kayes and Tinker 2012). To summarize, although there is considerable stand-to-stand variability, many, if not most, postoutbreak stands maintain lodgepole pine as a significant or dominant proportion of stems or basal area and maintain adequate stocking levels. See Cole and Amman (1980) and Shore et al. (2006) for more detailed discussions of MPB effects on lodgepole pine stand structure.

\section{Ponderosa Pine}

In ponderosa pine type, MPB-caused mortality is typically less dramatic, especially at the landscape scale. Outbreaks start as dispersed pockets of mortality that may grow and coalesce with successive beetle generations (Sartwell and Stevens 1975). As in lodgepole pine type, outbreaks can last for $\geq 10$ years (McCambridge et al. 1982, Schmid and Mata 1996). Many ponderosa pines survive MPB outbreaks even, unlike in lodgepole pine systems, among larger diameter classes. Indeed, although some investigators report a positive relationship between diameter and probability of infestation (Negron et al. 2008, Klenner and Arsenault 2009), others found little correlation beyond about $20 \mathrm{~cm} \mathrm{dbh}$ (McCambridge et al. 1982, Olsen et al. 1996). Stems smaller than $20 \mathrm{~cm}$ dbh are substantially less likely to become infested. McCambridge et al. (1982) observed a maximal stand-level mortality rate of $49 \%$ for stems of all size classes in a northern Colorado outbreak and suggested that complete stand mortality is uncommon. In the Black Hills of South Dakota, Allen et al. (2002) reported that 53\% of stems across multiple stands (drainage-scale surveys) had been killed in an ongoing outbreak and estimated that final mortality could 
- Generally, larger diameter lodgepole pine and whitebark pine are increasingly susceptible; the relationship between diameter and ponderosa pine susceptibility is uncertain, although trees $<20 \mathrm{~cm}$ dbh are less susceptible.

- Severe infestations can kill $\geq 95 \%$ of large diameter pines at the stand level, including up to $40 \%$ of overstory trees in a single year.

Landscape-level mortality rates are considerably less because of diversity in stand structure and composition.

Nonhost trees are rarely affected.

MPB outbreaks can last up to $10 \mathrm{yr}$ at the stand level and $\geq 10 \mathrm{yr}$ at the landscape level.

Although pine composition is reduced after a MPB outbreak, pines often remain the dominant species.

- Surviving lodgepole pine and whitebark pine generally come from smaller diameter classes, whereas surviving ponderosa pine may include trees from larger size classes.

- The density of surviving stems (all size classes and species) is generally $>500 \mathrm{ha}^{-1}$.

reach $80 \%$. Most southwestern-type ponderosa pines survived infestation at Utah, Arizona, and Colorado stands classified as epidemic or postepidemic with only $\sim 18 \%$ of total stems killed; even among stems $>20 \mathrm{~cm}$ dbh, rates were no higher than $31 \%$ (Chojnacky et al. 2000). In severely infested stands of southcentral British Columbia, Klenner and Arsenault (2009) measured 95\% mortality among stems $>30 \mathrm{~cm} \mathrm{dbh}$. At the landscape level, however, only $\sim 1 \%$ of the ponderosa pine forest was classified as having $>50 \%$ cumulative mortality among three provincial forest districts $(145,000-213,000$ ha each).

Severely infested stands notwithstanding (Allen et al. 2002, Klenner and Arsenault 2009), the residual forest contains many ponderosa pines, albeit at reduced densities and average diameters. After a Colorado outbreak, $75 \%$ of surveyed ponderosa pine stems survived (representing $64 \%$ of the preoutbreak basal area) including trees as large as $84 \mathrm{~cm}$ dbh (McCambridge et al. 1982). Even in the most heavily infested stands surveyed, the density of surviving ponderosa pines was $>700 \mathrm{ha}^{-1}$ with an average diameter of $13.7 \mathrm{~cm}$. After a South Dakota outbreak, $79 \%$ of preoutbreak ponderosa pine stems remained unattacked, including trees from all size classes, with a density of 483 stems ha $^{-1}$ (Olsen et al. 1996). Nonhost trees, of course, are not affected by infestation with the net result being that they will comprise a larger proportion of stems and basal area in the postoutbreak stand.

\section{Whitebark Pine}

Whitebark pines are periodically infested by MPBs, including an outbreak from 1909-1940 that killed many mature pines in the northern US Rockies (Arno and Hoff 1989). Among surveyed stands in central Idaho, most lost more than one-half of all whitebark pine stems, during this early 20th century outbreak, with few surviving trees larger than $20 \mathrm{~cm}$ dbh (Perkins and Roberts 2001). Surveyed stands in Montana lost 22-44\% of whitebark pines during a 1980s outbreak, mostly among larger diameter classes (Bartos and Gibson 1990). During the most recent outbreaks, MPB outbreaks killed $15-96 \%$ of whitebark pines among surveyed stands in Idaho, Montana, and Wyoming, mostly among larger diameter classes (Gibson et al. 2008). Thus, the postoutbreak forest will include mostly smaller diameter whitebark pines as well as any nonpines such as fir and spruce. Landscape-level whitebark pine mortality may be more severe than that in lodgepole or ponderosa pine systems. In an extensive assessment of aerial photography, $46 \%$ of $\sim 900,000$ ha of whitebark pine distribution in the Greater Yellowstone Ecosystem was classified with severe mortality (near complete loss of overstory pines) with another 36\% classified with moderate mortality (Macfarlane et al. 2013). See Table 1 for highlights of MPB-caused mortality patterns and residual forest conditions.

\section{Forest Development After Outbreaks Disturbance-Influenced Succession}

Lodgepole pine is a disturbance-adapted species that rapidly recolonizes landscapes after stand-replacing wildfires, often forming pure, even-aged stands (Lotan et al. 1985). Cone serotiny is variable, sometimes even within a stand, and, thus, seeds are released with or without fire, albeit exposed mineral soil enhances germinant success (Schoennagel et al. 2003). After multiple decades of development, stands become increasingly susceptible to MPB infestation (Amman et al. 1977). After a MPB outbreak, forest development depends on multiple factors including infestation severity, advance regeneration, the presence of nonhost trees, biogeography, and further disturbance such as wildfire (Shore et al. 2006).

Four successional roles have been described for lodgepole pine, ranging from prone to resistant to species conversion after MPB disturbance: (1) minor seral; (2) dominant seral; (3) persistent; and (4) climax (Pfister and Daubenmire 1975). Bark beetle outbreaks are widely observed to release the secondary stand structure (i.e., subcanopy and understory trees) (Axelson et al. 2010), which includes various amounts of lodgepole pine. Repeated MPB outbreaks without subsequent wildfire will hasten conversion to shade-tolerant species, although lodgepole pine may persist on some sites (Roe and Amman 1970). Many postoutbreak studies found lodgepole pine advance regeneration and seedling recruitment lacking compared with that of more shade-tolerant species, supporting the hypothesis that outbreaks result in successional acceleration (Page and Jenkins 2007, Sibold et al. 2007, Vyse et al. 2009, Collins et al. 2011, Pelz and Smith 2012, Kayes and Tinker 2012). The pace of conversion is partly dependent on species composition among advance regeneration, which itself may depend on stand age or successional status (Sibold et al. 2007, Hawkins et al. 2012). For example, a forest vegetation simulator predicted lodgepole pine among harvested stands, with a relatively high lodgepole pine component among advance regeneration and recruited seedlings, to remain the dominant species for $\sim 140$ years, whereas untreated stands, with less lodgepole pine in the understory, were predicted to become dominated by subalpine fir $\sim 90$ years postoutbreak (Collins et al. 2011). Regardless, future stand-replacing wildfires ensure the continued central role of lodgepole pine in these forests despite possible dominance by shade-tolerant associates after MPB outbreaks (Lotan et al. 1985, Minckley et al. 2012).

It should not be assumed, however, that lodgepole pine will be displaced from a stand or forest by MPB infestation. Multiple empirical studies demonstrate the resilience of this species even given the recent, severe MPB outbreaks. In central British Columbia, mixed severity wildfires and repeated MPB outbreaks have resulted in a landscape of multiaged lodgepole pine stands (Axelson et al. 
2010). This occurs because lodgepole pine is able to regenerate under its own canopy, coupled with fire exclusion of shade-tolerant advance regeneration in that region (Hawkes et al. 2004). In Colorado, heavily infested postoutbreak stands maintained dominance of lodgepole pine, in terms of basal area and density, across five forest types including two with shade-tolerant fir and spruce present (Diskin et al. 2011). In the region surveyed, the proportion of lodgepole pine-dominated landscape decreased only from $93 \%$ preoutbreak to $84 \%$ postoutbreak and about $40 \%$ of the landscape remained nearly pure lodgepole pine. In another Colorado survey conducted 30 years postoutbreak, lodgepole pine-dominated stands accounted for $77 \%$ of overstory basal area compared with $89 \%$ preoutbreak, whereas mixed conifer stands had 49\% lodgepole basal area compared with 66\% preoutbreak (Pelz and Smith 2012). After an outbreak in Wyoming, the spatial extent of three forest types (pure lodgepole pine, aspen-influenced, and spruce-fir) was apparently unchanged despite the loss of most overstory lodgepole pine (Kayes and Tinker 2012). Residual lodgepole pine in the overstory as well as that among advance regeneration contributed to a lack of conversion to shade-tolerant overstory species. In addition to reports of substantial, if not dominant, lodgepole pine among advance regeneration (Sibold et al. 2007, Vyse et al. 2009, Collins et al. 2011), lodgepole pine seedlings can also establish postoutbreak (Stuart et al. 1989, Sibold et al. 2007, Axelson et al. 2009, 2010, Collins et al. 2011). Thus, lodgepole pine often remains the dominant species even in heavily infested areas. In addition, considering the type's fire return interval of 22 to 310 years (Arno 1980, Schoennagel et al. 2003), this fire-adapted species will be favored over more shade-tolerant species before it is lost from a stand or forest (Lotan et al. 1985).

In ponderosa pine type, succession after disturbance depends on the presence, if any, of more shade-tolerant species such as Douglas-fir (Pseudotsuga menziesii [Mirbel] Franco) as well as the degree of canopy mortality. Under some conditions, ponderosa pine may be maintained on a site by low-severity disturbance (Graham and Jain 2005). In whitebark pine type, MPB disturbances may hasten succession to fir or spruce in some stands, whereas, in climax whitebark pine type, whitebark pine is self-regenerating (Bartos and Gibson 1990, Perkins and Roberts 2001).

\section{Response of Surviving Stems}

In the aftermath of a MPB outbreak, surviving trees gain increased access to limited resources such as water, light, and nutrients. Although surviving lodgepole pines generally are slower growing than the infested trees were before they were killed (Roe and Amman 1970, Pfeifer et al. 2010), these trees nevertheless respond to the reduced competition with increased radial growth rates (Axelson et al. 2009, 2010). In a mixed stand in British Columbia, for example, postoutbreak Douglas-firs gained an average 11.7\% diameter and lodgepole pines 5.4\% diameter compared with estimates of their size in the absence of MPB thinning (Heath and Alfaro 1990). Among postoutbreak plots in and around Yellowstone National Park, Romme et al. (1986) reported annual radial growth increases of 21-266\% among surviving lodgepole pines with the highest rates among understory stems. The release response began within 5 years after the peak outbreak and continued for up to 20 years, the maximum interval measured. Likewise, MPB outbreaks in Oregon resulted in the release of surviving overstory stems for $>20$ years (Stuart et al. 1989). Nearly full recovery to near preoutbreak levels of live basal area (and stem density) can be expected within
20-30 years (Pelz and Smith 2012). Among advance regeneration beneath a MPB-killed overstory, the annual height growth of lodgepole pine and subalpine fir doubled over 3 years (Collins et al. 2011).

\section{Advance Regeneration}

Advance regeneration is widely considered the most important source for replacing MPB-killed overstory stems (Astrup et al. 2008, Collins et al. 2011, Kayes and Tinker 2012, Pelz and Smith 2012), and these stems can respond more quickly to the modified forest conditions than postoutbreak recruited seedlings (Pelz and Smith 2012). Except for nearly pure lodgepole pine stands, advance regeneration typically includes a high proportion of shade-tolerant species, and lodgepole pine is often a minor component (Vyse et al. 2009, Collins et al. 2011, Kayes and Tinker 2012, Pelz and Smith 2012). Nevertheless, lodgepole pine advance regeneration can be abundant even in stands where the species is seral. In Colorado, for example, lodgepole pine advance regeneration stems averaged 1,207 $\mathrm{ha}^{-1}$ in harvested stands and $805 \mathrm{ha}^{-1}$ in untreated stands despite only representing 39 and 35\%, respectively, of total advance regeneration (Collins et al. 2011). Likewise in Wyoming, lodgepole pine advance regeneration averaged 971 stems ha ${ }^{-1}$ despite accounting for only 23\% of the total (Kayes and Tinker 2012). In nearly pure lodgepole pine stands, however, the understory may be dominated by that species. In surveys of Idaho, Utah, and Montana stands infested 3-80 years earlier, wherein lodgepole pine accounted for $84-100 \%$ of the basal area, lodgepole pine averaged $~ 90 \%$ of 1,195 stems ha ${ }^{-1}$ among saplings $(<7.6 \mathrm{~cm} \mathrm{dbh}$ but $>1.3 \mathrm{~cm}$ diameter at rootcollar); in the seedling size class $(<1.3 \mathrm{~cm}$ diameter at rootcollar), lodgepole pine stems average $\sim 89 \%$ of 15,108 stems ha ${ }^{-1}$ (author's unpublished data).

Regardless of shade tolerance, species among the preoutbreak overstory will be represented among advance regeneration (Kayes and Tinker 2012). In southcentral British Columbia, advance regeneration in surveyed stands averaged 2,689 stems ha ${ }^{-1}$ (range, $120-23,540$ ) with an inverse relationship between stem density and overstory basal area; lodgepole pine dominated the taller size classes and subalpine fir the shorter size classes (Nigh et al. 2008). In central British Columbia, advance regeneration was highly variable among stands but averaged 2,200-3,500 stems ha ${ }^{-1}$, depending on stand age class. Although spruce and fir dominated the smallest size class, a trend increasing with stand age, lodgepole pine was present among all stand age classes and all size classes (Hawkins et al. 2012). In a broad survey of MPB-affected stands in British Columbia, regeneration (advance regeneration and postoutbreak seedlings were not distinguished) was variable but nonetheless averaged 4,300-6,800 stems $\mathrm{ha}^{-1}$, including about 2,100 stems ha $^{-1}$ of lodgepole pine; less than $1 \%$ of surveyed plots lacked regeneration (LeMay et al. 2007). With or without lodgepole pine, these densities of advance regeneration are more than adequate to ensure fully stocked future stands.

\section{Seedling Recruitment}

Lodgepole pine seedling recruitment is variable after MPB outbreaks, ranging from sparse to very abundant. In central British Columbia, a moss-dominated forest floor apparently contributed to poor recruitment up to 10 years postoutbreak, especially for lodgepole pine (Astrup et al. 2008). In contrast, lodgepole pine stands in Colorado had substantial recruitment within 3 years postoutbreak, 
> Multiple factors shape postoutbreak stand development, including infestation severity, advance regeneration, presence of nonhost trees, biogeography, stand age, successional status, and further disturbance such as wildfire.

In all pine types, postoutbreak stand development may favor shade-tolerant species or maintenance of pine, depending on those factors.

- Advance regeneration responds quickly to MPB-modified forest conditions and is considered the most important source for replacing killed overstory.

- In mixed stands, advance regeneration may be dominated by shade-tolerant species.

- Advance regeneration in lodgepole pine type is typically more than adequate to ensure fully stocked stands.

- Surviving stems respond to postoutbreak conditions with increased radial growth rates, as high as 266\%, beginning within 5 yr of peak outbreak and continuing for $\geq 20 \mathrm{yr}$.

- Seedling recruitment into canopy gaps is typically substantial in lodgepole pine type and can include mostly lodgepole pine.

- Ponderosa pine recruitment may be enhanced by canopy gaps, although favorable weather or microsites may be more important.

- In whitebark pine, canopy gaps may be attractive to seed-caching Clark's nutcrackers, which favors pine establishment.

- Grasses, forbs, and shrubs may significantly increase in species diversity, cover, biomass, and/or height in postoutbreak stands compared with those in uninfested stands.

averaging 5,800 stems $\mathrm{ha}^{-1}$ (3,000 were lodgepole pine) in harvested stands and 1,800 stems ha $^{-1}$ ( 875 were lodgepole pine) in untreated stands (Collins et al. 2011). These recruited stems should join with advance regeneration in forming the new overstory, albeit seedling mortality rates will be very high at such densities. Recruited seedlings, combined with surviving overstory stems and advance regeneration, will transform a typical even-aged lodgepole pine stand into a multiaged, multistoried stand (Sibold et al. 2007, Axelson et al. 2009, Diskin et al. 2011). Episodic recruitment of lodgepole pine in MPB-caused canopy gaps has been reported from Oregon, Colorado, and British Columbia, and seedling density was correlated to the severity of MPB infestation (Stuart et al. 1989, Sibold et al. 2007, Axelson et al. 2009, 2010). The severity of disturbance, as well as stand age or successional status, may also influence the species composition of recruitment with higher severity events favoring lodgepole pine over more shade-tolerant species (Sibold et al. 2007, Axelson et al. 2009). Sibold et al. (2007) concluded the following: high-severity disturbance in relatively young lodgepole stands results in a pulse of lodgepole pine recruitment; high-severity disturbance in older stands results in mixed species recruitment; and moderate-severity disturbance in older stands favors fir establishment. The Sibold et al. (2007) rule well fits observations elsewhere wherein lodgepole pine or fir dominate among seedlings, depending on the forest type (e.g., Diskin et al. 2011, Kayes and Tinker 2012).

Thus, succession can be either paused or accelerated, depending on disturbance severity and stand age. An exception to the Sibold et al. (2007) model can be found among the results of Astrup et al. (2008); although greater MPB-caused mortality did correlate with greater seedling recruitment, fir was favored because it was less inhibited by the moss-dominated forest floor. Cone serotiny may also confound lodgepole pine colonization of canopy gaps, especially among younger stands that tend to have fewer open cones (Schoennagel et al. 2003, Sibold et al. 2007).

In ponderosa pine type, pine recruitment is uncertain after MPB disturbance. Although the resulting canopy gaps and reduced basal area may enhance successful pine regeneration (Lundquist and Negron 2000, Puhlick et al. 2012), recruitment is not necessarily correlated with areas of high overstory mortality (Boyden et al. 2005). Instead, favorable weather or microsites are probably more important for ponderosa pine recruitment (Brown and Wu 2005, Boyden et al. 2005, Puhlick et al. 2012). In whitebark pine type, pine recruitment was positively correlated to the proportion of over- story killed by MPB in stands surveyed in Montana, Idaho, and Oregon (Larson and Kipfmueller 2010 and references therein). The beetle-caused canopy gaps are apparently attractive to seed-caching Clark's nutcrackers and the presence of snags increases seedling survival in these high-elevation systems.

\section{Changes in Nontree Vegetation}

Stone and Wolfe (1996) conducted a study regarding the influence of MPB outbreak severity on nontree vegetation among lodgepole pine-dominated stands in Utah. The biomass of nontree vegetation was found to increase exponentially with increasing proportions of canopy killed, suggesting a positive response to increased photosynthetically active radiation (see Morehouse et al. 2008 for an example of postoutbreak changes in photosynthetically active radiation). Similarly, grasses, forbs, and shrubs were observed to have a 3-fold increase in Douglas-fir beetle (Dendroctonus pseudotsugae Hopkins)-infested Douglas-fir stands compared with that in uninfested stands in Wyoming (McMillin and Allen 2003). In MPB-infested lodgepole pine stands in Colorado, measured 0-7 years postoutbreak, the percent cover of nontree vegetation was not significantly different from that among uninfested stands although maximal grass and forb heights were significantly higher among infested stands (Klutsch et al. 2009). Among Stone and Wolfe's (1996) Utah plots, maximal understory species diversity was found among plots with moderate levels of mortality, consistent with the intermediate disturbance hypothesis. See Table 2 for highlights of postoutbreak forest development.

\section{Carbon Dynamics after MPB Outbreaks}

The death of some varying proportion of overstory trees during a MPB outbreak modifies carbon, nutrient, and water cycling in the affected system. The killed trees no longer take up carbon, and the loss of each stem contributes immediately to a decrease in site productivity. Infested stems are transferred from live to dead pools, increasing heterotrophic respiration but also decreasing autotrophic respiration (Edburg et al. 2011). These factors alter the balance of carbon fluxes in the affected area and, depending on outbreak severity, can result in switching systems from net carbon sinks to net carbon sources (Hicke et al. 2012 and references therein). Total plant uptake of nutrients is reduced, increasing the pool size of inorganic nitrogen available to surviving stems (Morehouse et al. 2008, Griffin et al. 2011), and the dynamic of 
microbial immobilization/mineralization of inorganic nitrogen may change as various components of the killed stems contact the forest floor and soil (Edburg et al. 2011). System evapotranspiration is reduced with the loss of overstory stems, and snowpack accumulation and ablation are modified, potentially increasing streamflows (Bewley et al. 2010). All of these processes are coupled. For example, the postoutbreak changes in soil moisture will alter decomposition and plant growth rates, in turn influencing net mineralization and nutrient uptake (Edburg et al. 2012). The ephemeral aspect of these impacts on carbon cycling, however, must be considered, and I will review their temporal character in the following sections.

\section{Reduction in Carbon Production}

To fully understand the impact of MPB outbreaks on carbon production, it is instructional to first consider temporal patterns in the absence of an intermediate disturbance (i.e., MPB outbreak) subsequent to a stand-replacing event. A widely observed pattern in even-aged forest development is a relatively early peak in gross (GPP) and net primary production (NPP) followed by a gradual decline, possibly to near steady-state conditions (Figure 1) (Ryan et al. 2004, Goulden et al. 2011). Given that lodgepole pine stand biomass increment peaks at age 30-60 years (Pearson et al. 1987, Ryan and Waring 1992, Smith and Resh 1999) and MPB infestations seldom initiate in stands $<60$ years old with stands aged $>80$ years at greatest risk of outbreak (Amman et al. 1977), it is likely that outbreaks are restricted to stands with reduced carbon productivity relative to maximal rates. Indeed, heightened MPB susceptibility among trees of reduced productive efficiency has been shown for lodgepole and ponderosa pines (Mitchell et al. 1983, Larsson et al. 1983).

Nevertheless, MPB outbreaks result in further reduced production for years to decades (Figure 1) or longer (Pfeifer et al. 2010). Among lodgepole pine stands in and around Yellowstone National Park, Wyoming, postoutbreak annual wood production was reduced $\sim 25 \%$ relative to that of uninfested controls (Romme et al. 1986). Using input data from infested plots in central Idaho, empirically based growth-and-yield model simulations found that aboveground carbon accumulation was reduced by $12-51 \%$ as a result of a MPB outbreak (Pfeifer et al. 2010). Using a process-based ecosystem model and a hypothetical infestation, Edburg et al. (2011) found that the infestation reduced GPP by almost $60 \%$ and NPP by $~ 30 \%$. With use of an empirically driven ecological process model, landscape level $\left(374,000 \mathrm{~km}^{2}\right) \mathrm{NPP}$ was estimated to be reduced from an average of $440 \mathrm{~g} \mathrm{C} \mathrm{m}^{-2}$ in 2000 to $400 \mathrm{~g} \mathrm{C} \mathrm{m}^{-2}$ in 2009 during the recent outbreak in British Columbia (Kurz et al. 2008). In these studies, recovery generally began within a few years postoutbreak, albeit at different rates, depending on multiple factors. In Romme et al.'s (1986) Wyoming study, infested stands returned to preoutbreak wood production levels after 5-15 years and exceeded the preoutbreak level in one stand. Preoutbreak biomass and productivity were concentrated among canopy stems, whereas postoutbreak, they were more evenly distributed among canopy, subcanopy, and understory trees. In another Wyoming study, carbon production was not significantly different among stands infested 25-30 years before measurement and similarly aged uninfested stands (Kashian et al. 2013). In Pfeifer et al.'s (2010) simulations of Idaho stands, conducted using the secondary stand structure but not recruitment, aboveground carbon production did not return to preoutbreak levels during 200-year simulations for any of 12 stands, although it did rebound from postoutbreak minimums
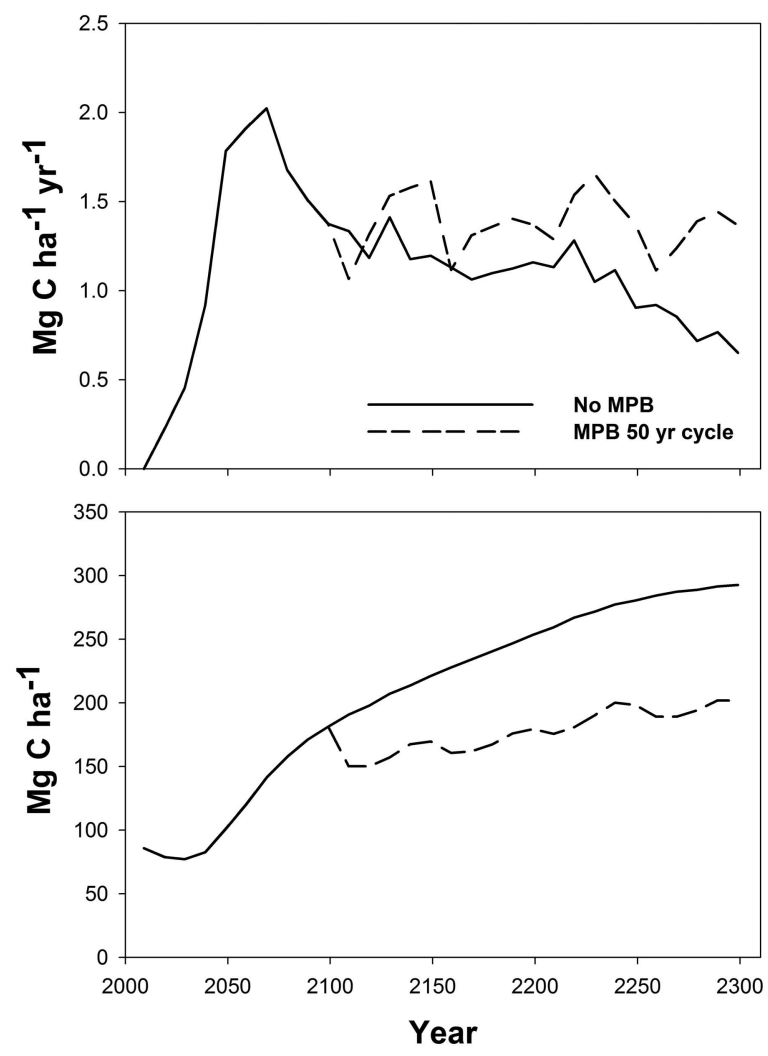

Figure 1. Aboveground net primary productivity in trees (top panel) and total system carbon storage (all compartments represented except mineral soil; bottom panel) in 300-year simulations using the empirically based Forest Vegetation Simulator (FVS). Simulations used the Tetons variant of the FVS loutput in 10-year time steps), the Fire and Fuels Extension to generate total system carbon, and the Mountain Pine Beetle Extension to simulate mortality. Initial snag and downed woody material carbon were averaged from that of two recently burned stands (author's unpublished data). Initial live tree density was 3,100 lodgepole pine ha ${ }^{-1}$, the median postfire density reported by Turner et al. (2004). At each subsequent 10-year time step, recruitment was specified as 12.5 lodgepole pine, 7.5 subalpine fir, and 2.5 whitebark pine $\mathrm{ha}^{-1}$. The carbon mass of individual stems was calculated at each time step using allometric equations (Lambert et al. 2005) and carbon concentrations of tree components (author's unpublished data); NPP was calculated by summing the time step averaged annual carbon increment of individual surviving trees ("Approach 1" in Clark et al. 2001). MPB outbreaks were manually scheduled every 50 years beginning at stand age 100 years, with a pulse of lodgepole pine recruitment $\left(1,000\right.$ stems $\left.\mathrm{ha}^{-1}\right)$ one time step later.

in most cases. Uninfested simulations also exhibited declining production, however, and the infested and uninfested simulations had matching carbon production levels after 29-161 years. This range in timing was influenced by overstory mortality rates and the density of smaller, more productive surviving stems. For one stand wherein postoutbreak pine recruitment was simulated (300 stems ha ${ }^{-1}$ ), annual production was boosted by up to $11 \%$, mostly during the first 75 years postoutbreak (Pfeifer et al. 2010). Among Edburg et al.'s (2011) process-based simulations, postoutbreak GPP recovered to $80 \%$ of GPP in the uninfested control simulation within 10 years. Full recovery to uninfested values occurred after $\sim 40$ years (note that these simulations did not explicitly include age-related declines in carbon productivity which particularly affect uninfested stands; see Figure 1). Several factors were found to affect the rate of recovery 
including the severity and duration of the outbreak as well as timing to snagfall initiation and rates of subsequent snagfall (Edburg et al. 2011), the effects of which will be addressed in the next section.

\section{Decomposition of Coarse Woody Debris and the Forest Floor}

Because larger canopy trees are killed during MPB outbreaks, a considerable amount of material is transferred to dead matter pools. After a high-severity outbreak in lodgepole pine in central Idaho, for example, Pfeifer et al. (2010) determined that 6-65\% of aboveground live biomass was killed by beetles. Across all plots, this was $54 \%$ of all lodgepole pine stems, representing an average of $\sim 19 \mathrm{Mg}$ $\mathrm{C} \mathrm{ha}{ }^{-1}$. Components of this dead material have various degrees of quality and recalcitrance to decomposition. Moreover, decomposition rates are dramatically slower for tree components not in contact with the ground, and aboveground components may not fall for years to decades.

In Edburg et al.'s (2011) simulations, coarse root carbon in dead pools accumulated during each year of the infestation and then decreased because of decomposition. Fine roots can be expected to decay first and fastest because they are relatively high quality (low carbon/nitrogen ratio) and in an environment favorable for microbial success (relative to aboveground substrates; see below). Coarse roots are more recalcitrant owing to their lower quality and greater volume. In a Wyoming study, lodgepole pine roots 5 - to $10-\mathrm{mm}$ in diameter had exponential decay coefficients $(k)$ of $0.0404-0.0624$ (half-life, 11-17 years), whereas 26- to 50-mm roots had $k$ ranging from 0.024 to 0.0293 (half-life, 24-29 years) (Yavitt and Fahey 1982). Among other variables, temperature and moisture will influence decomposition rates for lodgepole and ponderosa pines (Chen et al. 2000). Thus, rates will vary among ecosystems as well as seasonally and with year-to-year weather variations. Soil carbon stocks may be increased by bark beetle disturbance. Using a hybrid empirically based growth and yield/ecological process model, Seidl et al. (2008) found greater soil carbon (forest floor and mineral soil combined) among 100-year simulations that included bark beetle series compared with undisturbed series in Norway spruce.

Because needles from killed pines begin to fall about 1 year after infestation with most needles fallen within 5 years, a severe infestation can be expected to result in a pulse of litterfall and forest floor accumulation. For example, infested stands measured 4-7 years postoutbreak in Colorado had significantly greater litter depth than more recently infested and uninfested stands (Klutsch et al. 2009, Moore et al. 2013). In a northwest Wyoming study, however, lodgepole pine litter biomass did not significantly differ among uninfested, red stage ( $\sim 2$ years postattack), gray stage ( $\sim 4$ years postattack), and 30 years postattack stands (Griffin et al. 2011). Among stands surveyed in Idaho, Utah, and Montana, including some infested within 5 years of measurements, no significant differences were found in the forest floor biomasses of infested and uninfested plots (author's unpublished data). In an Arizona study conducted 2 years after peak outbreak (mortality caused by multiple Dendroctonus and Ips species), forest floor biomasses under infested and uninfested ponderosa pine stands were not significantly different despite most needles having fallen from infested trees (Morehouse et al. 2008). Moreover, needlefall was significantly greater among uninfested plots; litterfall was not significantly different (Morehouse et al. 2008). Counterintuitively, Kashian et al. (2013) found significantly greater forest floor biomass among stands infested 25-30 years before measurement compared with similarly aged, uninfested stands. As with all compartments, forest floor biomass is a function of inputs (litterfall) and outputs (decomposition). Thus, the uninfested stands, with significantly greater live overstory biomass, should be expected to have greater litterfall than stands infested many years earlier. That is, infested stands should have a pulse of increased litterfall within the first few years postoutbreak but, thereafter, have significantly reduced litterfall because of the reduction in live canopy. Conceivably, the foliar biomasses among postoutbreak stands in Kashian et al.'s (2013) study could have recovered such that they surpassed that of uninfested stands.

In addition, relatively quick decomposition of litter will offset any temporary increase in litterfall after just a few years. In a Wyoming study, decomposing lodgepole pine needles lost $\sim 20 \%$ mass annually, indicating a half-life of about 3 years (Fahey 1983). Using litterbags at infested and uninfested plots in Idaho, Utah, and Montana, the half-life of forest floor lodgepole pine foliage was estimated to be $2-2.5$ years; rates were not significantly different among infested and uninfested plots (author's unpublished data). Thus, the lack of conspicuous differences in forest floor accumulations among uninfested and recently infested stands might be explained by the following: relatively quick decomposition of litterfall coupled with delayed and uneven needle loss from individual trees; the pattern and timing of MPB attacks within a stand (see Host Mortality Patterns and Residual Forest); and the fact that uninfested trees continue to produce litter irrespective of the disturbance (Simard et al. 2012). Regardless, the pulse of foliar carbon inputs from MPBkilled trees is relatively minor compared with that from other compartments. For example, Edburg et al.'s (2011) simulations, which focused on extreme infestation scenarios, showed foliar carbon (and nitrogen) to have little effect on system dynamics, especially compared with belowground and bole components.

The lack of favorable aboveground conditions for decay organisms is evident among reported decomposition rates for snags. Harvey (1986) reported $<1 \%$ volume loss 11 years after death by MPB in Oregon, and in Wyoming, Fahey (1983) found no significant decline in specific gravity of 5- to 12-year old snags compared with living trees, whereas 20 -year-old snags retained $\sim 95 \%$ of original specific gravity. The decomposition rate increases after snags fall and contact the ground (note that "jackstrawed" downfall may remain elevated above the forest floor for many years or decades after snagfall). Rates continue to remain low, however, in absolute terms. In Oregon, Busse (1994) reported a $k$ of 0.027 (half-life, $\sim 26$ years), whereas Fahey (1983) reported a $k$ of 0.0163 (half-life, $\sim 43$ years) for a Wyoming forest. In Colorado, most lodgepole pine bole volume remained intact after multiple decades on the ground, including one bole dated as dying 139 years before being measured (Brown et al. 1998). In lodgepole and ponderosa pine, snagfall is minimal for the first 5 years. In Oregon lodgepole pine, 50\% of snags fell after 8-9 years (Mitchell and Preisler 1998). In Utah, 5-40\% of infested lodgepole pine stems remained standing on plots measured $\sim 25$ years after infestation, although all snags had fallen in Idaho and Montana plots infested $\sim 35$ years before measurement (author's unpublished data). In California and Oregon ponderosa pine, most snags fell 5-15 years after beetle infestation with $\sim 10 \%$ standing after 25 years (Keen 1955), whereas infested Colorado ponderosa pine fell at 3-5\% year ${ }^{-1}$ unless affected by high winds (Schmid et al. 1985). In some systems, snags can remain standing for many decades. For example, whitebark pine snags were common 70 years after a MPB outbreak dated circa 1930 (Perkins and Roberts 2001). 


\section{Net Carbon Fluxes}

In the preceding sections, I reviewed evidence that loss of live overstory results in substantial, if temporary, reductions in NPP and that decomposition, and by extension, heterotrophic respiration, should increase commensurate with increases in dead matter pools (although note that heterotrophic respiration rates may be confounded by complex changes in microclimate; see Morehouse et al. 2008, Bewley et al. 2010, and Griffin et al. 2011 for examples of postoutbreak changes in solar radiation, air temperature, soil temperature, and soil moisture). These factors will shift the net carbon balance of affected ecosystems (Hicke et al. 2012). In process model simulations for British Columbia, landscape-level heterotrophic respiration increased by $6 \%$ in conjunction with a $10 \%$ loss in NPP (Kurz et al. 2008). The result shifted the landscape from a net carbon sink in $2000\left(0.59 \mathrm{Mt} \mathrm{C}\right.$ year $\left.{ }^{-1}\right)$ to a net carbon source in 2009 ( $\sim 20 \mathrm{Mt} \mathrm{C}$ year $\left.^{-1}\right)$. Net biome production then recovered, but the system remained a net carbon source through 2020, the end of the simulation (Kurz et al. 2008).

Smaller scale studies found more moderate impacts of MPB outbreaks. For example, eddy covariance data from two severely infested lodgepole pine stands in British Columbia (60-95\% canopy mortality), measured 1-5 years postoutbreak, showed higher than expected net ecosystem productivity (NEP) (Brown et al. 2010, 2012). Values were only slightly negative, recovering to near neutral by the fifth year. This finding was attributed to increased productivity by the surviving secondary stand structure as well as shrubs and herbs, and heterotrophic respiration was not observed to substantially increase (Brown et al. 2010, 2012). Eddy covariance data from infested stands in northcentral Colorado showed that GPP declined $13.8 \%$, but respiration was reduced by nearly as much $(12.4 \%)$, resulting in only a modest decline in carbon sink capacity during the first 6 years postoutbreak (Moore et al. 2013). In an analysis of eddy covariance data of multiple forest disturbance events throughout North America, including the Brown et al. (2010) data, it was concluded that all measured systems recovered from being a net carbon source to sink within 10-20 years after stand-replacing disturbance (i.e., wildfire) (Amiro et al. 2010). Intermediate disturbances, including bark beetle outbreaks, exhibited smaller decreases in NEP and even faster recoveries.

The process-based modeling of Edburg et al. (2011) is instructional for understanding the underlying processes that determine net carbon flux for an infested system. Using an extreme baseline scenario ( $95 \%$ lodgepole pine mortality over a 3 -year outbreak), heterotrophic respiration increased substantially, compared with that for an uninfested simulation, for the first $\sim 5$ years postoutbreak as labile carbon sources (needles and fine roots) were consumed. Thereafter, heterotrophic respiration fell below that of the uninfested simulation until the snags fell and began to decompose. Even then, heterotrophic respiration was only slightly elevated, relative to that for the uninfested simulation, as decomposition of coarse woody debris was drawn out for several decades. Meanwhile, postoutbreak autotrophic respiration fell in proportion to reductions in GPP, dwarfing the short-lived spike in heterotrophic respiration (Edburg et al. 2011). The balance of these processes should be reduced soil respiration. Empirical data are generally consistent with this modeling. For example, stands in northcentral Colorado were observed to have a strong decline $(40 \%)$ in soil respiration (i.e., combined autotrophic and heterotrophic respiration) during the first 3 years postoutbreak with nearly full recovery after $\sim 6$ years, the increase corresponding to the litter pulse as needles fell from infested trees (Moore et al. 2013). On the other hand, infested and uninfested ponderosa pine stands in Arizona had similar soil respiration rates 2 years postoutbreak, suggesting that decreased autotrophic respiration and increased heterotrophic respiration cancelled each other (Morehouse et al. 2008). The Edburg et al. (2011) simulations also exhibited a quick recovery in postoutbreak GPP. After a trough $\sim 5$ years postoutbreak, GPP fully recovered to uninfested simulation levels after 40 years. The net result in dynamics of autotrophic carbon uptake and respiration plus heterotrophic respiration was that NEP recovered to $80 \%$ of uninfested simulation levels within 5 years, became carbon neutral after $\sim 23$ years, and matched uninfested simulation levels after 40 years. Edburg et al. (2011) also simulated less severe outbreaks. In a simulation with $25 \%$ mortality, all fluxes were more closely aligned with those of the uninfested simulations, and NEP remained positive for most years. Modifying the duration of the outbreak affected fluxes on the order of years rather than decades. Timing of snagfall initiation and subsequent snagfall rates also influenced flux trajectories. These variables affected not only heterotrophic respiration through time but also GPP/NPP because of assumptions in plant-available nitrogen as a result of microbial immobilization/mineralization. At the end of 100 -year simulations; however, outbreak severity was the only variable that substantially modified cumulative NEP (Edburg et al. 2011).

\section{Carbon Storage}

Growth-and-yield models indicate that total system carbon storage is affected by MPB outbreaks (Figure 1). As described in the preceding sections, the temporal pattern of carbon loss in infested stands compared with that in uninfested stands may be more a function of temporarily reduced carbon production rather than of increased heterotrophic respiration. Regardless, carbon stocks in MPB-affected stands may take longer to recover than flux rates. Live vegetation carbon did not return to preoutbreak levels for 100 years in Edburg et al.'s (2011) simulations (total system carbon was not reported). In Pfeifer et al.'s (2010) simulations for infested stands, total aboveground biomass needed $1-25$ years to return to preoutbreak levels. Stands in the uninfested simulations, however, continued to accrue biomass over a 200-year trajectory, and aboveground carbon stocks in infested simulations did not match those of uninfested simulations for 56-185 years. Nevertheless, Pfeifer et al. (2010, p. 11) concluded that their simulations demonstrated "significant resiliency of (carbon) storage to beetle-caused mortality." In contrast to simulated data, empirical data show similar total carbon stocks among mature uninfested and infested stands. For example, Kashian et al. (2013) found no significant differences in total stand carbon among six lodgepole pine stands in Yellowstone National Park infested 25-30 years before measurement and six uninfested stands (stands were aged 134-262 years). Likewise, uninfested mature stands in central Idaho, southwest Montana, and northeast Utah did not have significantly more total carbon than stands infested 3-80 years before measurement (author's unpublished data). See Table 3 for highlights of carbon dynamics after MPB outbreaks and Hicke et al. (2012) for additional perspectives regarding the effects of forest insects, including mountain pine beetle, and diseases on carbon dynamics in North American forests.

\section{Summary}

MPB outbreaks result in the death of many, most, or, possibly, all mature pines at the stand level. Infestations have decreasing impact, 
> MPB outbreaks affect multiple, coupled ecosystem processes such as carbon uptake and storage, nutrient uptake and storage, and evapotranspiration and water cycling, as well as modify environmental conditions such as forest temperatures and available sunlight.

- MPB outbreaks transfer carbon from live to dead pools, increasing heterotrophic respiration but also decreasing autotrophic respiration.

> During the first few years after MPB outbreaks, stand-level carbon productivity may be reduced by more than 50\% compared with preoutbreak productivity.

Recovery begins within a few years; some stands may return to preoutbreak productivity levels in as few as 5 yr, whereas others, although rebounding from postoutbreak lows, may never fully return to preoutbreak levels.

- In uninfested stands, carbon productivity peaks at age 24-60 yr and then slowly declines over the life of the stand; thus, recovering infested stands may have greater average carbon production depending on the time scale considered and the response to the partial disturbance.

$>$ Snags, which undergo almost no decomposition, may remain standing for $\sim 10 \mathrm{yr}$ and perhaps much longer; downed boles typically require many decades to decompose.

- Any postoutbreak increase in forest floor biomass, from the litter of infested trees, and associated heterotrophic respiration rates will be shortlived due to relatively quick decomposition of this substrate.

Autotrophic inputs, rather than heterotrophic consumption, are the primary drivers of lodgepole pine system carbon dynamics.

Affected ecosystems can switch from net carbon sinks to net carbon sources, depending on outbreak severity, among other factors.

- Recovery to net carbon sinks occurs within 5-20 yr even for severely infested stands; moderately infested stands may remain net carbon sinks despite infestation.

- Trends in postoutbreak carbon storage are uncertain; empirical studies (with small sample sizes) indicate that total system carbon storage is essentially unaffected by MPB outbreaks, whereas model simulations suggest that infestations reduce carbon storage relative to undisturbed stands.

- Regardless of levels relative to uninfested stands, carbon stocks in infested stands remain high in absolute terms due to recalcitrance of coarse woody debris coupled with recovering live carbon pools.

however, at larger spatial scales because of diversity in stand structure and composition. Regardless of the stand-level mortality rates, surviving stem density is usually adequate to meet stocking levels prescribed by foresters. Although survivors may include overstory pine stems, increasing infestation severity results in increasing proportional dominance of subcanopy pine stems, advance regeneration, and nonpines. Surviving stems are released from competition, and seedlings are typically recruited into the canopy gaps. Succession to more shade-tolerant species may be paused or accelerated, depending on multiple factors. Under certain conditions, lodgepole pine may continue to dominate the forest despite periodic disturbance by MPB (Figure 2).

These changes in forest structure, which vary with time since MPB disturbance, modify carbon dynamics. The loss of each MPBkilled tree causes an immediate decrease in stand carbon productivity. Simultaneously, the transfer of biomass from live to dead pools potentially results in increased heterotrophic respiration as substrates become available for microbial consumption. Labile, highquality carbon substrates (e.g., fine roots and needles) are consumed within a few years of tree death, although a potentially large spike in stand- and forest-scale heterotrophic respiration may be subdued by the delay between individual stem mortality and needle loss as well as by temporal and spatial infestation patterns. Snags are practically unaffected by decomposition until they fall and contact the ground. Even then, coarse woody debris is recalcitrant and only gradually lost from local carbon pools over multiple decades. The effects of changes in NPP and decomposition on net carbon balances are further confounded by substantial decreases in autotrophic respiration. The magnitude of changes in net carbon balance is partly dependent on infestation severity. Stands with extreme mortality rates are more likely to result in temporarily becoming net carbon sources, but such levels of infestation are uncommon at the landscape level even after severe outbreak events. At the forest and landscape levels, changes in carbon production and net carbon balance will be moderated because of diversity in stand structure and other factors affecting MPB-caused mortality rates.
The reduction in NPP after outbreaks is temporary as carbon production rebounds beginning $\sim 5$ years postoutbreak due to responses of secondary stand structure, nontree vegetation, and recruited seedlings. Because repeated, moderate-severity disturbances in forested systems sustain carbon productivity (Kimmins 1987), it might be predicted that MPB outbreaks result in cumulative productivity equal to, if not higher than, that under scenarios without disturbance (Figure 1). Although GPP or NPP is only temporarily set back by MPB outbreaks, carbon storage may be substantially affected, in comparison to that for uninfested stands, over long time spans (Figure 1; although see Kashian et al. 2013). Nevertheless, total system carbon stocks remain high, in absolute terms, because of recalcitrant snag and coarse woody debris pools combined with recovering stocks in live pools, plus stable, if not increasing, forest floor and mineral soil pools. Among stands wherein MPB infestation results in a switch of net carbon balance from sink to source, return to net carbon sink occurs within 5-20 years (Amiro et al. 2010, Edburg et al. 2011, Brown et al. 2012, Moore et al. 2013).

Ecosystems recover from disturbances regardless of the disturbance agent or severity. Unavoidably, these systems will again become increasingly susceptible to another disturbance as biomass accumulates (Holling 1992). Theoretical evidence from the field of thermodynamics suggests that these cycles of ecosystem development and destruction are the result of local energy imbalances (Kay 2000). That is, ecosystem disturbance and recovery are intertwined ecological processes, probably driven by inexorable broad-scale drivers. Although different developmental pathways become possible with each iteration of postdisturbance reorganization, lodgepole pine, in particular, is a disturbance-adapted species that persists on landscapes despite repeated MPB outbreaks and wildfire. Relative to stand-replacing events (e.g., wildfire), MPB outbreaks are intermediate disturbance agents that leave substantial secondary stand structure. As such, postoutbreak forest recovery proceeds relatively quickly. Live basal area, stem density, carbon productivity, and net carbon balance recover to preoutbreak values within 5-40 years, although impacts to total carbon storage may be longer lasting. 

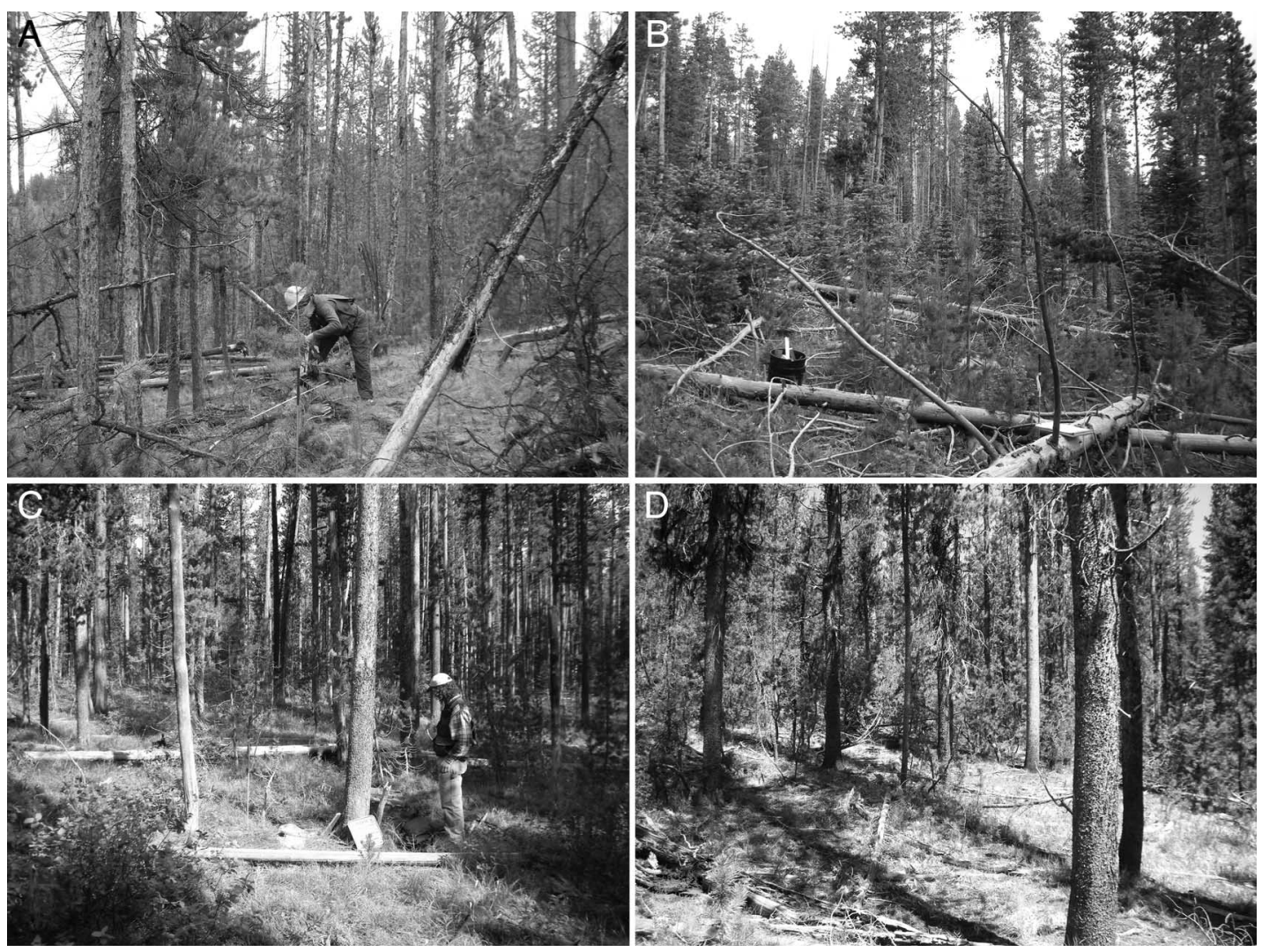

Figure 2. Lodgepole pine stand development after MPB disturbance. A. At 10 years postoutbreak (Sawtooth National Forest, ID; this stand was also infested $\sim 80$ years before the image was taken). B. At $\sim 25$ years postoutbreak (Ashley National Forest, UT). C. At 35 years postoutbreak (Gallatin National Forest, MT). D. At $\sim 80$ years postoutbreak (Boise National Forest, ID). Notice (1) the persistence of downed woody material even at 80 years postoutbreak, (2) the conversion to multistoried and multiaged stand, (3) the abundance of surviving secondary stand structure as well as postoutbreak seedling recruitment, and (4) the continued lodgepole pine dominance of these stands (which were probably $100 \%$ lodgepole pine overstory at the time of the infestations). (Photos by author.)

\section{Literature Cited}

Alfaro R.I., R. Campbell, P. Vera, B. Hawkes, and T. Shore. 2004. Dendroecological reconstruction of mountain pine beetle outbreaks in the Chilcotin Plateau of British Columbia. P. 245-256 in Challenges and solutions: Proc. of the Mountain pine beetle symposium; Kelowna, BC; Oct. 30-31, 2003, Shore, T.L., J.E. Brooks, and J.E. Stone (eds.). Natural Resources Canada, Info. Rep. BC-X-399, Canadian Forest Service, Pacific Forestry Centre, Victoria, BC, Canada.

ALLEN, K.K., W.C. SCHAUPP, AND D.F. LONG. 2002. Evaluation of mountain pine beetle activity in the Beaver Park area of the Black Hills National Forest. USDA For. Serv., Biol. Eval. R2-03-03, Rocky Mountain Region, Renewable Resources, Forest Health Management, Lakewood, CO. 14 p.

Amiro, B.D., A.G. Barr, J.G. Barr, T.A. Black, R. Bracho, M. BRown, J. ChEN, ET AL. 2010. Ecosystem carbon dioxide fluxes after disturbances in forests of North America. J. Geophys. Res. 115:G00K02; doi:10.1029/2010JG001390.

AmmAn, G.D. 1977. The role of the mountain pine beetle in lodgepole pine ecosystems impact on succession. P. 3-18 in The role of arthropods in forest ecosystems: Proc., 15th International congress of entomology; Washington, DC, Aug. 19-27, 1976, Mattson, W.J. (ed.). Springer-Verlag, New York.

Amman, G.D., M.D. McGregor, D.B. Cahill, And W.H. Klein. 1977. Guidelines for reducing losses of lodgepole pine to the mountain pine beetle in unmanaged stands in the Rocky Mountains. USDA For. Serv., Gen. Tech. Rep. INT-36, Intermountain Research Station, Ogden, UT. 19 p.

ARNO, S.F. 1980. Forest fire history in the Northern Rockies. J. For. 78(8):460-465.

ARNO, S.F., AND R.J. Hoff. 1989. Silvics of whitebark pine (Pinus albicau- lis). USDA For. Serv., Gen. Tech. Rep. INT-253, Intermountain Research Station, Ogden, UT. 11 p.

Astrup, R., K.D. COATES, AND E. HALl. 2008. Recruitment limitation in forests: Lessons from an unprecedented mountain pine beetle outbreak. For. Ecol. Manage. 256:1743-1750.

AXElson, J.N., R.I. Alfaro, AND B.C. HaWkes. 2009. Influence of fire and mountain pine beetle on the dynamics of lodgepole pine stands in British Columbia, Canada. For. Ecol. Manage. 257:1874-1882.

Axelson, J.N., R.I. Alfaro, AND B.C. HawKes. 2010. Changes in stand structure in uneven-aged lodgepole pine stands impacted by mountain pine beetle epidemics and fires in central British Columbia. For. Chron. 86(1):87-99.

BARTOS, D.L., AND K.E. GIBSON. 1990. Insects of whitebark pine with emphasis on mountain pine beetle. P. 171-178 in Proc. of the Symposium on whitebark pine ecosystems: Ecology and management of a highmountain resource; Bozeman, MT; March 29-31 1989, Schmidt, W.C., and K.J. MacDonald (eds.). USDA For. Serv., Gen. Tech. Rep. INTGTR-270, Intermountain Research Station, Ogden, UT. 386 p.

Bentz, B., C.D. Allen, M. Ayres, E. Berg, A. Carroll, M. Hansen, J. HICKE, ET AL. 2009. Bark beetle outbreaks in western North America: Causes and consequences: Proc.: Bark beetle symposium. Snowbird, UT; Nov. 15-17, 2005. The University of Utah Press, Salt Lake City, UT. $42 \mathrm{p}$.

Bentz, B.J., J. Régnière, C.J. Fettig, E.M. Hansen, J.L. Hayes, J.A. Hicke, R.G. Kelsey, J.F. Negrón, And S.J. Seybold. 2010. Climate change and bark beetles of the Western United States and Canada: Direct and indirect effects. BioScience 60(8):602-613.

Bewley, D., Y. Alila, AND A. VARHOla. 2010. Variability of snow water 
equivalent and snow energetics across a large catchment subject to mountain pine beetle infestation and rapid salvage logging. J. Hydrol. 388:464-479.

BOYDEN, S., D. BinKLEY, AND W. SHEPPARD. 2005. Spatial and temporal patterns in structure, regeneration, and mortality of an old-growth ponderosa pine forest in the Colorado Front Range. For. Ecol. Manage. 219:43-55.

Brown, M., T.A. Black, Z. Nesic, V.N. Foord, D.L. Spittlehouse, A.L. Fredeen, N.J. Grant, P.J. Burton, AND J.A. Trofymow. 2010. Impact of mountain pine beetle on the net ecosystem production of lodgepole pine stands in British Columbia. Agr. For. Meteorol. 150:254-264.

Brown, M.G., T.A. Black, Z. Nesic, A.L. FredeEn, V.N. Foord, D.L. SpitTlehouse, R. Bowler, ET AL. 2012. The carbon balance of two lodgepole pine stands recovering from mountain pine beetle attack in British Columbia. Agr. For. Meteorol. 153:82-93.

Brown, P.M., W.D. Sheppard, S.A. MatA, AND D.L. MCClain. 1998. Longevity of windthrown logs in a subalpine forest of central Colorado. Can. J. For. Res. 28:932-936.

BROWN, P.M., AND R. WU. 2005. Climate and disturbance forcing of episodic tree recruitment in a Southwestern ponderosa pine landscape. Ecology 86(11):3030-3038.

BRunelle, A., G.E. ReHFeldT, B. BentZ, AND A.S. Munson. 2008. Holocene records of Dendroctonus bark beetles in high elevation pine forests of Idaho and Montana, USA. For. Ecol. Manage. 255(3-4):836-846.

Busse, M.D. 1994. Downed bole-wood decomposition in lodgepole pone forests of central Oregon. Soil Sci. Soc. Am. J. 58:221-227.

Chen, H., M.E. Harmon, R.P. GriffTiHs, AND W. Hicks. 2000. Effects of temperature and moisture on carbon respired from decomposing woody roots. For. Ecol. Manage. 138:51-64.

Chojnacky, D.C., B.J. Bentz, AND J.A. Logan. 2000. Mountain pine beetle attack in ponderosa pine: Comparing methods for rating susceptibility. USDA For. Serv., Res. Pap. RMRS-RP-26, Rocky Mountain Research Station, Fort Collins, CO. 10 p.

Clark, D.A., S. Brown, D.W. Kicklighter, J.Q. Chambers, J.R. THOMLINSON, AND J. Ni. 2001. Measuring net primary productivity in forests: concepts and field methods. Ecol. Applic. 11:356-370.

Coates, K.D., C. DeLong, P.J. BurTON, AND D.L. SACHS. 2006. Abundance of secondary structure in lodgepole pine stands affected by the mountain pine beetle. Available online at www.for.gov.bc.ca/hfp/mountain pine_beetle/stewardship/report.pdf; last accessed Dec. 6, 2012.

Cole, W.E., AND G.D. AmMAN. 1980. Mountain pine beetle dynamics in lodgepole pine forests. Part I: Course of an infestation. USDA For. Serv., Gen. Tech. Rep.INT-89, Intermountain Research Station, Ogden, UT. $56 \mathrm{p}$.

Cole, W.E., G.D. Amman, And C.E. Jensen. 1976. Mathematical models for the mountain pine beetle-lodgepole pine interaction. Environ. Entomol. 5(1):11-19.

Collins, B.J., C.C. Rhoades, R.M. Hubbard, and M.A. BatTaglia. 2011. Tree regeneration and future stand development after bark beetle infestation and harvesting in Colorado lodgepole pine stands. For. Ecol. Manage. 261:2168-2175.

DE la Giroday, H.-M.C., A.L. Carroll, And B.H. AuKeMa. 2012. Breach of the northern Rocky Mountain geoclimatic barrier: Initiation of range expansion by the mountain pine beetle. J. Biogeogr. 39:1112-1123.

Diskin, M., M.E. RoccA, K.N. Nelson, C.F. AOKI, AND W.H. ROMmE. 2011. Forest developmental trajectories in mountain pine beetle disturbed forests of Rocky Mountain National Park, Colorado. Can. J. For. Res. 41:782-792.

Edburg, S.L., J.A. Hicke, P.D. Brooks, E.G. Pendall, B.E. Ewers, U. Norton, D. Gochis, E.D. Gutmann, And A.J.H. Meddens. 2012. Cascading impacts of bark beetle-caused tree mortality on coupled biogeophysical and biogeochemical processes. Front. Ecol. Environ. 10(8):416-424.1890/110173.
EdburG, S.L., J.A. Hicke, D.M. LAWrenCE, AND P.E. ThOrNTON. 2011. Simulating coupled carbon and nitrogen dynamics following mountain pine beetle outbreaks in the western United States. J. Geophys. Res. 116:G04033; doi:10.1029/2011JG001786.

FAHEY, T.J. 1983. Nutrient dynamics of above-ground detritus in lodgepole pine ecosystems, southeastern Wyoming. Ecol. Monogr. 53:51-72.

FURNISS, R.L., AND V.M. CAROLIN. 1977. Western forest insects. USDA For. Serv., Misc. Publ. 1339, Washington, DC. 654 p.

Gibson, K., K. Skov, S. Kegley, C. Jorgensen, S. Smith, And J. WiTCOSKY. 2008. Mountain pine beetle impacts in high-elevation five-needle pines: Current trends and challenges. USDA For. Serv., For. Health Protection Rep. R1-08-020, Missoula, MT. 32 p.

Goulden, M.L., A.M.S. McMillan, G.C. Winston, A.V. Rocha, K.L. Manies, J.W. Harden, B.P. Bond-Lamberty. 2011. Patterns of NPP, GPP, respiration, and NEP during boreal forest succession. Glob. Change Biol. 17:855-871.

Graham, R.T., AND T.B. JaIn. 2005. Ponderosa pine ecosystems. USDA For. Serv., Gen. Tech. Rep. PSW-GTR-198, Pacific Southwest Research Station, Berkeley, CA. 281 p.

Griffin, J.M., M.G. Turner, And M. Simard. 2011. Nitrogen cycling following mountain pine beetle disturbance in lodgepole pine forests of Greater Yellowstone. For. Ecol. Manage. 261:1077-1089.

HARVEY, R.D. 1986. Deterioration of mountain pine beetle-killed lodgepole pine in northeast Oregon. USDA For. Serv., Report R6-86-13, Portland, OR. 10 p.

Hawkes, B., S. Taylor, C. Stockdale, T. Shore, R. Alfaro, R. CampBELL, AND P. VERA. 2004. Impact of mountain pine beetle on stand dynamics in British Columbia. P. 177-199 in Mountain pine beetle symposium: Challenges and solutions, October 30-31, 2003, Shore, T.L., J.E. Brooks, and J.E. Stone (eds.). Natural Resources Canada, Info. Report B.C.-X-399, Canadian Forest Service, Pacific Forestry Centre, Victoria, BC, Canada.

Hawkins, C.D.B., A. Dhar, N.A. Balliet, and K.D. Runzer. 2012. Residual mature trees and secondary stand structure after mountain pine beetle attack in central British Columbia. For. Ecol. Manage. 277:107-115.

Heath, R., and R. Alfaro. 1990. Growth response in a Douglasfir/lodgepole pine stand after thinning of lodgepole pine by the mountain pine beetle. J. Entomol. Soc. BC 87:16-21.

Hicke, J.A., C.D. Allen, A. Desai, M.C. Dietze, R.J. Hall, E.H. HoGG, D.M. KaSHIAN, ET AL. 2012. Effects of biotic disturbances on forest carbon cycling in the United States and Canada. Global Change Biol. 18:7-34.

Holling, C.S. 1992. Cross-scale morphology, geometry and dynamics of ecosystems. Ecol. Monogr. 62(4):447-502.

Huber, D.P.W., B.H. AuKEMA, R.S. Hodgkinson, AND B.S. LindGREN. 2009. Successful colonization, reproduction, and new generation emergence in live interior hybrid spruce Picea engelmannii $\times$ glauca by mountain pine beetle Dendroctonus ponderosae. Agr. For. Entomol. 11: 83-89.

KASHIAN, D.M., R.M. JACKSON, AND H.D. LYONS. 2011. Forest structure by mountain pine beetle outbreaks affects subsequent attack in a Wyoming lodgepole pine forest, USA. Can. J. For. Res. 41:2403-2412.

Kashian, D.M., W.H. Romme, D.B. Tinker, M.G. Turner, And M.G. RYAN. 2013. Post-fire changes in forest carbon storage over a 300-year chronosequence of Pinus contorta-dominated forests. Ecol. Monogr. $83: 49-66$.

KAY, J. 2000. Ecosystems as self-organizing holarchic open systems: Narratives and the second law of thermodynamics. P. 135-160 in Handbook of ecosystem theories and management, Jorgensen, S.E., and F. Muller (eds.). Lewis Publishers, Boca Raton, FL.

KaYeS, L.J., AND D.B. TinKER. 2012. Forest structure and regeneration following a mountain pine beetle epidemic in southeastern Wyoming. For. Ecol. Manage. 263:57-66. 
KEEN, F.P. 1955. The rate of natural falling of beetle-killed ponderosa pine snags. J. For. 55:720-723.

Kimmins, J.P. 1987. Forest ecology. Macmillan Publishing Company, New York. 531 p.

Klein, W.H., D.L. PARKER, AND C.E. JENSEN. 1978. Attack, emergence, and stand depletion trends of the mountain pine beetle in a lodgepole pine stand during an outbreak. Environ. Entomol. 7:732-737.

KlenNer, W., AND A. ArSenault. 2009. Ponderosa pine mortality during a severe bark beetle (Coleoptera: Curculionidae, Scolytinae) outbreak in southern British Columbia and implications for wildlife habitat management. For. Ecol. Manage. 258:S5-S14.

Klutsch, J.G., J.F. Negrón, S.L. Costello, C.C. RhoAdes, D.R. WEST, J. POPP, AND R. CAISSIE. 2009. Stand characteristics and downed woody debris accumulations associated with a mountain pine beetle outbreak in Colorado. For. Ecol. Manage. 258:641-649.

Kurz, W.A., C.C. Dymond, G. Stinson, G.J. Rampley, E.T. Neilson, A.L. Carroll, T. Ebata, AND L. SafranyiK. 2008. Mountain pine beetle and forest carbon feedback to climate change. Nature 452: 987-990.

LAMBERT, M.-C., C.-H. UnG, AND F. RAulier. 2005. Canadian national tree aboveground biomass equations. Can. J. For. Res. 35:1996-2018.

LARSON, E.R., AND K.F. KipfmUelLer. 2010. Patterns in whitebark pine regeneration and their relationships to biophysical site characteristics in southwest Montana, central Idaho, and Oregon, USA. Can. J. For. Res. 40:476-487.

LARSSON, S., R. OrEn, R.H. WARING, AND J.W. BARRETT. 1983. Attacks of mountain pine beetle as related to tree vigor of ponderosa pine. For. Sci. 29(2):395-402.

LeMay, V., T. Lee, D. Sattler, P. Marshall, D. Robinson, and A. ZUMRAWI. 2007. Modeling natural regeneration following mountain pine beetle attacks in the southern and central interior of British Columbia. Natural Resources Canada, Mountain Pine Beetle Working Pap. 2007-16, Canadian Forest Service, Pacific Forestry Centre, Victoria, BC, Canada. 51 p.

LOTAN, J.E., J.K. BROWN, AND L.F. NEUENSCHWANDER. 1985. Role of fire in lodgepole pine forests. P. 133-152 in Lodgepole pine: The species and its management; May 1984; Spokane, WA, and Vancouver, BC, Baumgartner, D.M., R.G. Krebill, J.T. Arnott, and G.F. Weetman (eds.). Washington State University Cooperative Extension, Pullman, WA.

LundQuist, J.E., AND J.F. NEGRÓN. 2000. Endemic forest disturbances and stand structure of ponderosa pine (Pinus ponderosa) in the Upper Pine Creek Research Natural Area, South Dakota, USA. Natural Areas J. 20:126-132.

Macfarlane, W.W., J.A. LOGAN, AND W.R. KeRN. 2013. An innovative aerial assessment of Greater Yellowstone Ecosystem mountain pine beetle-caused whitebark pine mortality. Ecol. Applic. 23:421-437.

McCambridge, W.F., F.G. HawKSworth, C.B. Edminster, AND J.G. LAUT. 1982. Ponderosa pine mortality resulting from a mountain pine beetle outbreak. USDA For. Serv., Res. Paper RM-235, Rocky Mountain Research Station, Fort Collins, CO. 7 p.

MCMillin, J.D., AND K.K. Allen. 2003. Effects of Douglas-fir beetle (Coleoptera: Scolytidae) infestations on forest overstory and understory conditions in western Wyoming. West. North Am. Naturalist 63(4):498-506.

MiNCKLEY, T.A., R.K. SHRIVER, AND B. SCHUMAN. 2012. Resilience and regime change in a southern Rocky Mountain ecosystem during the past 17000 years. Ecol. Monogr. 82(1):49-68.

Mitchell, R.G., AND H.K. Preisler. 1998. Fall rate of lodgepole pine killed by the mountain pine beetle in central Oregon. West. J. Appl. For. 13(1):23-26.

Mitchell, R.G., R.H. Waring, and G.B. Pitman. 1983. Thinning lodgepole pine increases tree vigor and resistance to mountain pine beetle. For. Sci. 29(1):204-211.

Moore, D.J.P., N.A. Trahan, P. Wilkes, T. Quaife, B.B. STePhens, K.
Elder, A.R. Desai, J.F. Negrón, And R.K. Monson. 2013. Persistent reduced ecosystem respiration after insect disturbance in high elevation forests. Ecol. Lett. 16(6):731-737.

Morehouse, K., T. Johns, J. Kaye, And M. Kaye. 2008. Carbon and nitrogen cycling immediately following bark beetle outbreaks in southwestern ponderosa pine forests. For. Ecol. Manage. 255:2968-2708.

Negrón, J.F., K. Allen, B. CoOK, AND J.R. Withrow. 2008. Susceptibility of ponderosa pine, Pinus ponderosa (Dougl. Ex Laws.), to mountain pine beetle, Dendroctonus ponderosae Hopkins, attack in unevenaged stands in the Black Hills of South Dakota and Wyoming USA. For. Ecol. Manage. 254:327-334.

Nigh, G.D., J.A. ANTOS, AND R. PARISH. 2008. Density and distribution of advanced regeneration in mountain pine beetle killed lodgepole pine stands of the Montane Spruce zone of southern British Columbia. Can. J. For. Res. 38(11):2826-2836.

OlsEN, W.K., J.M. SCHMID, AND S.A. MATA. 1996. Stand characteristics associated with mountain pine beetle infestations in ponderosa pine. For. Sci. 42:310-327.

Page, W.G., And M.J. JenKINS. 2007. Mountain pine beetle-induced changes to selected lodgepole pine fuel complexes within the intermountain region. For. Sci. 53:507-518.

Pearson, J.A., D.H. KNIGHT, And T.J. Fahey. 1987. Biomass and nutrient accumulation during stand development in Wyoming lodgepole pine forests. Ecology 68:1966-1973.

PELZ, K.A., AND F.W. SMITH. 2012. Thirty year change in lodgepole and lodgepole/mixed conifer structure followings 1980s mountain pine beetle outbreak in western Colorado, USA. For. Ecol. Manage. 280:93-102.

PERKINS, D.L., AND D.W. ROBERTS. 2001. Predictive models of whitebark pine mortality from mountain pine beetle. For. Ecol. Manage. 174:495-510.

Pfeifer, E.M., J.A. Hicke, AND A.J.H. Meddens. 2010. Observations and modeling of aboveground tree carbon stocks and fluxes following a bark beetle outbreak in the western United States. Global Change Biol. 17:339-350.

Pfister, R.D., AND R. DAUbENMiRe. 1975. Ecology of lodgepole pine (Pinus contorta Douglas). P. 27-46 in Management of lodgepole pine ecosystems: Symposium proceedings; Pullman, WA; Oct. 9-11, 1973, Baumgartner, D.M. (ed.). Washington State University Cooperative Extension Service, Pullman WA.

Prigogine, I., AND I. STEngers. 1984. Order out of chaos. Bantam, New York. 349 p.

Puhlick, J.J., D.C. Laughlin, And M.M. MoOre. 2012. Factors influencing ponderosa pine regeneration in the southwestern USA. For. Ecol. Manage. 264:10-19.

Rehfeldt, G.E., N.L. Crookston, C. SÁenz-Romero, and E.M. CAMPBELL. 2012. North American vegetation model for land-use planning in a changing climate: A solution to large classification problems. Ecol. Applic. 22(1):119-141.

RoE, A.L., AND G.D. Amman. 1970. The mountain pine beetle in lodgepole pine forests. USDA For. Serv., Gen. Tech. Rep. INT-70, Intermountain Research Station, Ogden, UT. 23 p.

Romme, W.H., D.H. KNIGHT, AND J.B. YavitT. 1986. Mountain pine beetle outbreaks in the Rocky Mountains: Regulators of primary productivity? Am. Naturalist 127:484-494.

Ryan, M.G., D. Binkley, J.H. Fownes, C.P. GiardinA, AND R.S. SENOCK. 2004. An experimental test of the causes of forest growth decline with stand age. Ecol. Monogr. 74:393-414.

RYAN, M.G., AND R.H. WARING. 1992. Maintenance respiration and stand development in a subalpine lodgepole forest. Ecology 73:2100-2108.

SAFRANYIK, L. 2004. Mountain pine beetle epidemiology in lodgepole pine. P. 33-40 in Proc. of the Mountain pine beetle symposium: Challenges and solutions; Kelowna, BC; Oct.30-31, 2003, Shore, T.L., J.E. Brooks, and 
J.E. Stone (eds.). Natural Resources Canada, Info. Report BC-X-399, Canadian Forest Service, Pacific Forestry Centre, Victoria, BC, Canada.

Sartwell, C., AND R.E. STEVens. 1975. Mountain pine beetle in ponderosa pine: prospects for silvicultural control in second-growth stands. J. For. 73(3):136-140.

SCHMID, J.M., AND S.A. MATA. 1996. Natural variability of specific forest insect populations and their associated effects in Colorado. USDA For. Serv., Gen. Tech. Rep. RM-GTR-275, Rocky Mountain Research Station, Fort Collins, CO. 14 p.

SCHMID J.M., S.A. MATA, AND W.F. MCCAMBRIDGE. 1985. Natural falling of beetle-killed ponderosa pine. USDA For. Serv., Res. Note RM454, Rocky Mountain Research Station, Fort Collins, CO. 14 p.

Schoennagel, T., M.G. TuRnER, AND W.H. Romme. 2003. The influence of fire interval and serotiny on postfire lodgepole pine density in Yellowstone National Park. Ecology 84:1967-1978.

SEIDL, R., W. Rammer, D. JAGER, AND M.J. LeXER. 2008. Impact of bark beetle (Ips typographus L.) disturbance on timber production and carbon sequestration in different management strategies under climate change. For. Ecol. Manage. 256:209-220.

SHORE, T.L., L. SAFRANYIK, B.C. HAWKES, AND S.W. TAYLOR. 2006. Effects of the mountain pine beetle on lodgepole pine stand structure and dynamics. P. 95-114 in The mountain pine beetle: A synthesis of biology, management and impacts on lodgepole pine, Safranyik, L., and B. Wilson (eds.). Canadian Forest Service, Victoria, BC, Canada.

Sibold, J.S., T.T. Veblen, K.ChipKo, L. Lawson, E. Mathis, and J. SCOTT. 2007. Influences of secondary disturbances on lodgepole pine stand development in Rocky Mountain National Park. Ecol. Applic. 17:1638-1655.

Simard, M., W.H. Romme, J.M. Griffin, AND M.G. Turner. 2012. Do mountain pine beetle outbreaks change the probability of active crown fire in lodgepole pine forests? Reply. Ecology 93(4):946-950.
SMITH, F.W., AND S.C. ReSH. 1999. Age-related changes in production and below-ground carbon allocation in Pinus contorta forests. For. Sci. 45:333-341.

STONE, W.E., AND M.L. WOLFE. 1996. Response of understory vegetation to variable tree mortality following a mountain pine beetle epidemic in lodgepole pine stands in northern Utah. Plant Ecol. 122(1):1-12.

STUART, J.D., J.K. AGEE, AND R.I. GARA. 1989. Lodgepole pine regeneration in an old, self-perpetuating forest in south central Oregon. Can. J. For. Res. 19:1096-1104.

STURGEON, K.B., AND J.B. MiTTON. 1982. Evolution of bark beetle communities. P. 350-384 in Bark beetles in North American forests: A system for the study of evolutionary biology, Mitton, J.B., and K.B. Sturgeon (eds.). University of Texas Press, Austin, TX.

Turner, M.G., D.B. Tinker, W.H. Romme, D.M. Kashian, And C.M. LITTON. 2004. Landscape patterns of sapling density, leaf area, and aboveground net primary production in postfire lodgepole pine forests, Yellowstone National Park (USA). Ecosystems 7:751-775.

Vyse, A., C. Ferguson, D. Huggard, J. Roach, And B. Zimonick. 2009. Regeneration beneath lodgepole pine dominated stands attacked or threatened by the mountain pine beetle in the south central interior, British Columbia. For. Ecol. Manage. 258(Suppl.): S36-S43.

Walton, A. 2011. Provincial-level projection of the current mountain pine beetle outbreak: update of the infestation projection based on the 1999 to 2010 Provincial Aerial Overviews of Forest Health (BCMPB v8). British Columbia Ministry of Forests, Lands and Natural Resource Operations, Victoria, BC, Canada. 15 p.

YAVITT, J.B., AND T.J. FAHEY. 1982. Loss of mass and nutrient changes of decaying woody roots in lodgepole pine forests, southeastern Wyoming. Can. J. For. Res. 12:745-752. 